Behavioural

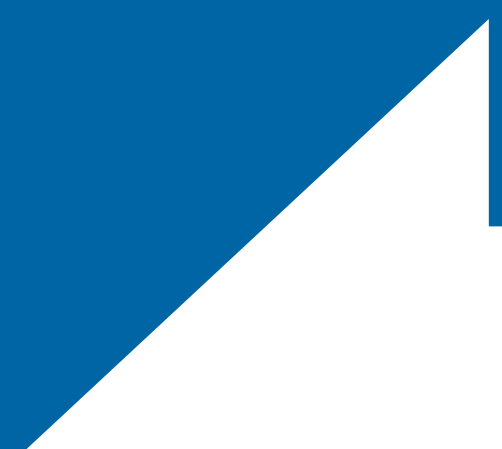

and Cognitive

\title{
Psychotherapy
}

journals.cambridge.org/bcp 


\section{Behavioural and Cognitive Psychotherapy}

AN INTERNATIONAL MULTIDISCIPLINARY JOURNAL FOR THE HELPING PROFESSIONS

\section{EDITOR}

Paul M Salkovskis

Behavioural and Cognitive Psychotherapy

Oxford Institute of Clinical Psychology Training,

Isis Education Centre, Warneford Hospital,

Headington, Oxford OX3 7JX, UK

\section{EDITORIAL ASSISTANT}

Lydia Holt

journal.office@babcp.com

\section{ASSOCIATE EDITORS}

Per Carlbring (Stockholm, Sweden)

Janet Carr (London, UK)

Fiona Challacombe (London, UK)

Jo Daniels (Bath, UK)
Hermine Graham (Birmingham, UK)

James Gregory (Bath, UK)

Rachel Hiller (Bath, UK)

Jason Jones (Oxford, UK)

Peter Langdon (East Anglia, UK)

Warren Mansell (Manchester, UK)

Rebecca Murphy (Oxford, UK)

Katharine Rimes (London, UK)

Craig Steel (Reading, UK)

Charlotte Wilson (Dublin, Ireland)

Kim Wright (Exeter, $U K$ )

Abigail Wroe (London, UK)

\section{BOOK REVIEW EDITORS}

Jessica Bird (Oxford, UK)

Peter Lawrence (Reading, UK)

\section{INTERNATIONAL EDITORS}

Cristina Botella (Castellón, Spain): Spanish language (Europe); Jean Cottraux (Lyons, France): French language; Laura Hernandez Guzman (Mexico City, Mexico): Spanish language (The Americas); Winfried Rief (Marburg, Germany): German language; Ezio Sanavio (Padova, Italy): Italian language.

\section{EDITORIAL BOARD}

Mark Freeston (Newcastle, UK), Sarah Halligan (Bath, UK), Claudia Herbert (Witney, UK), Mike Kyrios (Hawthorn, Australia), Irina Lazarova (Sofia, Bulgaria) Zhanjiang Li (Beijing, China), Yutaka Ono (Tokyo, Japan), Jón F. Sigurðsson (Reykjavík, Iceland), David Veale (London, UK).

\section{EDITORIAL ADVISORY BOARD}

Nada Anic (Croatia), Eiríkur Örn Arnarson (Iceland), Max Birchwood (UK), Kelly Brownell (USA), Isobel Caro (Spain), Edward Craighead (USA),

Paul Eelen (Belgium), Paul Emmelkamp (The Netherlands), Kurt Hahlweg (Germany), Iver Hand (Germany), Ray Hodgson (UK),

David Horne (Australia), Justin Kenardy (Australia), Philip Kendall (USA), Peter Lee (Hong Kong), Isaac Marks (UK), Andrew Mathews (UK),

Lars-Goran Ost (Sweden), José Pinto Gouveia (Portugal), Christine Purdon (Canada), Susan Robinson (UK), Gudrun Sartory (Germany),

Mehmet Z. Sungur (Turkey), Peter Vassiliev (Bulgaria), Hans-Ulrich Wittchen (Germany), G Terry Wilson (USA), William Yule (UK).

\section{SUBMISSION OF PAPERS}

Papers should be submitted, in accordance with the Instructions to Authors which can be found on the Journal's webpage at https://www.cambridge.org/core/journals/ behavioural-and-cognitive-psychotherapy/information/instructions-contributors to the Editor through the online submissions portal. Books for review should be sent to journal.office@babcp.com

\section{SUBSCRIPTIONS}

Behavioural and Cognitive Psychotherapy (ISSN 1352-4658) is published six times a year in Jan, Mar, May, Jul, Sep, Nov. Six parts form a volume. Volume 47 will appear in 2019 by Cambridge University Press, UPH, Shaftesbury Road, Cambridge CB2 8BS, UK/Cambridge University Press, 1 Liberty Plaza, Floor 20, New York, NY 10006, USA.

The annual subscription price (which includes delivery by air but excludes VAT) of Volume 47 is $£ 438$ (US $\$ 818$ in the USA, Canada and Mexico) for institutions print and electronic, institutions electronic only $£ 324 / \$ 607 ; £ 155$ (US\$287 in the USA, Canada and Mexico) for individuals ordering direct from the publisher and certifying that the journal is for their personal use. Single parts are $£ 84$ (US\$157 in the USA, Canada and Mexico) plus postage.

Orders, which must be accompanied by payment, may be sent to a bookseller, subscription agent or direct to the publisher: Cambridge University

Press, Journals Fulfillment Department, UPH, Shaftesbury Road, Cambridge CB2 8BS, UK; or in the USA, Canada and Mexico: Cambridge University Press, Journals Fulfillment Department, Cambridge University Press, 1 Liberty Plaza, Floor 20, New York, NY 10006, USA. EU subscribers (outside the UK) who are not registered for VAT should add VAT at their country's rate. VAT registered subscribers should provide their VAT registration number. Japanese prices for institutions are available from: Kinokuniya Company Ltd., PO Box 55, Chitose, Tokyo 156, Japan.

Periodical postage paid at New York, N.Y. and additional mailing offices. Postmaster: send address changes in USA, Canada and Mexico to: Behavioural and Cognitive Psychotherapy, Cambridge University Press, 1 Liberty Plaza, Floor 20, New York, NY 10006, USA.

Claims for missing issues should be made immediately on receipt of the subsequent issue.

\section{Advertising}

Apply to the publisher. Advertising queries for all parts of the world except the USA, Canada and Mexico to:

ad_sales@cambridge.org

Address enquiries in the USA, Mexico and Canada only to:

USAdSales@cambridge.org

Copyright (c) 2019 British Association for Behavioural and Cognitive Psychotherapies.

\section{Copying}

This journal is registered with the Copyright Clearance Center, 222 Rosewood Drive, Danvers, MA 01923, USA. Organisations in the USA who are also registered with C.C.C. may therefore photocopy material (beyond the limits permitted by sections 107 and 108 of U.S. Copyright law) subject to payment to C.C.C. of the per-copy fee of $\$ 20.00$. This consent does not extend to multiple copying for promotional or commercial purposes. Code 1352-4658/2019.

ISI Tear Sheet Service, 3501 Market Street, Philadelphia, PA 19104, USA, is authorised to supply single photocopies of separate articles for private use only.

Organisations authorised by the UK Copyright Licensing Agency may also photocopy material subject to the usual conditions. For all other use, permission should be sought from Cambridge or the American Branch of Cambridge University Press.

No part of this publication may otherwise be reproduced, stored or distributed by any means without permission in writing from Cambridge University Press, acting for the copyright holder.

Information on Behavioural and Cognitive Psychotherapy and other journals published by Cambridge University Press may be accessed via www.cambridge.org/BCP

\section{BABCP Membership}

Correspondence concerning membership of the British Association for Behavioural and Cognitive Psychotherapies should be addressed to British Association for Behavioural \& Cognitive Psychotherapies Imperial House, Hornby Street, Bury, BL9 5BN, Tel: 0161705 4304, Fax: 0161 705 4306, Web: www.babcp.com, 